\title{
Right of entry or right of refusal? Hospitality in the law of nature and nations
}

\author{
GIDEON BAKER*
}

\begin{abstract}
This article explores the account of international hospitality found in the natural law tradition from Vitoria to Kant. Rather than limit itself to intellectual history, the focus here is on a more enduring theme: the double-bind of hospitality which the natural lawyers encountered in seeking to find a place for the welcome of the foreigner in the law of nations'. Although these thinkers agreed on a natural right of communication, this proved destabilising, even destructive, of the property claims by which hosts establish their domain as properly theirs in the first place. All struggled with this double-bind, though this took different forms, from the concern that the law of hospitality might thereby justify colonial appropriation to fears for how it could threaten sovereignty. Two thinkers arguably find a way out of the double-bind of right of communication-right of property in hospitality, but sacrifice the law of hospitality in the process: Pufendorf, subordinating communication to property, turns hospitality into charity and thereby effectively denies it status as a law of nature; Kant, putting communication first, makes hospitality a matter of right, not philanthropy, but also sees it as instrumental to the development of a global civil condition, where it would be redundant.
\end{abstract}

Gideon Baker is Senior Lecturer in Politics and Public Policy at Griffith University, Queensland, Australia. His has published on various themes in international political theory, most recently on the ethics of hospitality. On this topic his Politicizing Ethics in International Relations: Cosmopolitanism as Hospitality is forthcoming with Routledge.

This article engages the idea of a law of hospitality which was articulated in the natural law tradition from Vitoria up to, and including, Kant - Kant's being the last significant contribution to this tradition. It argues that the account of hospitality in the 'law of nations' provided by this early modern tradition of thought was bounded by two poles - right of communication and right of property - which, while mutually constitutive of a law of hospitality, also continually threatened to unravel it. While any law of hospitality requires that travellers have rights to hospitable treatment, it also depends upon their hosts having some claim to exclusive property in their domains or territories. The tension between these two irreducible poles of hospitality, a feature of hospitality that Jacques Derrida has demonstrated in quite other contexts, is, it is argued, an enduring feature of otherwise very different accounts of the law of hospitality in the early modern

\footnotetext{
* I would like to thank Georg Cavaller, Richard Devetak and Ian Hunter for their invaluable feedback on earlier versions of this article. Though none of them would read the law of nature and nations as I do here, I am very grateful for their constructive criticisms. Thanks also to two anonymous reviewers for their insightful comments.
} 
natural law tradition. ${ }^{1}$ Three of the natural lawyers who consider hospitality in some detail, namely Vitoria, Grotius and Vattel (Vitoria and Vattel are the focus of section one), make little headway in stabilising the two poles of right of communication - right of property in hospitality, despite tending towards different poles (Vitoria towards right of communication and Vattel towards right of property). Pufendorf and Kant, the subjects of sections two and three respectively, make more headway in stabilising their discussions of hospitality, Pufendorf by prioritising property and Kant in the name of communication. However, the price paid for this stabilisation of the terms of international hospitality in these two accounts is fatal to the law of hospitality itself - in Pufendorf's case because hospitality is reduced to charity, thereby ceasing to function as right of nature; in Kant's because, though it is a matter of right, hospitality is instrumentalised, operating as the means to the accomplishment of a cosmopolitan constitutional condition under which such a right of hospitality would be rendered obsolete.

After Kant, hospitality, along with the natural law tradition in which it was embedded, largely disappears from accounts of the international, and this is typically held to be due to its eclipse by the rising nationalism and legal positivism of the early nineteenth century - the latter view leading to the rejection of natural rights as, in Bentham's well-known phrase, so much 'nonsense on stilts'. ${ }^{2}$ The trend towards constructions of a historical sociology, rather than a natural law, of hospitality begins even earlier, in the Scottish Enlightenment's dismissal, reflecting aspects of Montesquieu's critique, ${ }^{3}$ of hospitality as bucolic backwardness characterised by the idle and wasteful indulgence of feudal elites prior to the emergence of a more 'cultivated', commercial age. ${ }^{4}$ We do not encounter much thought of international hospitality again until its reappearance, if only implicitly, in the refugee and asylum provisions of international law after 1945. Perhaps this is unsurprising since current international law is built, amongst other things, on an idea of human rights which is itself to some extent a reactivation of natural law themes. $^{5}$

The importance of hospitality to early modern accounts of the international stemmed from the widely held view that, as an outworking of innate human sociability, there was a natural right of communication. ${ }^{6}$ Hospitality, the welcome

${ }^{1}$ Jacques Derrida, Adieu: to Emmanuel Levinas, trans. P. Brault and M. Nass (Stanford CA: Stanford University Press, 1999); Jacques Derrida, Of Hospitality, trans. R. Bowlby (Stanford CA: Stanford University Press, 2000); Jacques Derrida, On Cosmopolitanism and Forgiveness, trans. M. Dooley and M. Hughes (London: Routledge, 2001).

2 Anthony Pagden, 'Human Rights, Natural Rights, and Europe's Imperial Legacy', Political Theory, 31:2 (2003), pp. 171-99; Georg Cavallar, The Rights of Strangers: theories of international hospitality, the global community, and political justice since Vitoria (Aldershot: Ashgate, 2002).

${ }^{3}$ Baron de Montesquieu, Complete Works, vol. 2 The Spirit of Laws (London: T. Evans, 1777 [1748]), pp. $144-5$.

4 David Hume, Political Essays (Cambridge: Cambridge University Press, 1994 [1748]), p. 122; Adam Smith, An Inquiry into the Nature and Causes of the Wealth of Nations (New York: Random House, 1994 [1776]), pp. 440-1. However, see Rousseau for a characteristically contrary view to his enlightenment contemporaries. Jean-Jacques Rousseau, The Levite of Ephraim, in C. Kelly and E. Grace (eds), Rousseau on Women, Love, and Family (Hanover NH: Dartmouth College Press, 2009 [1762]), pp. 178-93.

5 Pagden, 'Human Rights, Natural Rights'.

${ }^{6}$ The emphasis on sociability obviously had a strongly theological dimension, as in Vitoria's argument that human communication and cooperation are God's will. Thanks to an anonymous reviewer for this point. 
of the stranger, was thereby seen as a key tenet of the law of nature and nations. Anthony Pagden has described an 'evolving' European idea, from the sixteenth to eighteenth centuries, of a common human identity or 'world civilization' made up of differing societies that nonetheless all subscribed to certain 'natural' rules or objectives which set the terms of 'natural rights'. Crucially, this implied something like a right of free passage. ${ }^{7}$ Pagden reads the early sixteenth century Spanish scholastic, Francisco de Vitoria, as marking the point at which the Aristotelian, specifically Thomist, account of the loss of mankind's original liberties is initially interpreted as an incomplete process in which the 'right of natural partnership and communication' is retained. ${ }^{8}$ Vitoria, claims Pagden, is thus the first to turn hospitality from an ancient Greek custom to a right under the law of nations. Pagden also reminds us of the ancient roots of this right of communication in the humanist tradition going back to the Stoics, who worked with the idea of a common law for all humanity. ${ }^{9}$ Thus Grotius utilised both Vitoria's neo-Thomist reasoning and various Stoic thinkers, including Seneca, in order to develop his own account of a principle of 'natural society and communication' as set out in The Freedom of the Seas (1607). Grotius drew on the Stoic sense that a world of widely distributed goods and the communication and commerce this necessitated were an expression of divine purpose. After Grotius we get Vattel's 'ties of the universal society which nature has established among men' and, finally, Kant's Stoicinfluenced (by Cicero, in particular) right of communication under the cosmopolitan law of hospitality as set out in Perpetual Peace. ${ }^{10}$ In short, for the natural law tradition stretching from Vitoria to Kant (with the exception of Pufendorf), the right of communication, and by extension, of hospitality, is a key tenet of the law of nature itself. Because the right of communication stems from the very nature of humans as social animals, hospitality is seen by some as a perfect right that no human agency can abrogate, including, fatally, native hosts of inhospitable - as in colonising - European guests. ${ }^{11}$

It is of course possible to see the natural lawyers' discourse on hospitality as less tied to imperial imperatives than Pagden does. A different reading would point to a gradual move away from an initial emphasis on the perfect right of hospitality enjoyed by European guests on savage shores (which reflected concerns arising out of the European voyages of discovery in the early sixteenth century) and towards a more universalistic account of an imperfect right which hosts are morally bound to honour in the case of necessitous guests only (such as the shipwrecked and others whose death will result if a welcome is refused). Also, while Vitoria sees the natural law of hospitality as implying rights of residence, later theorists, including (in)famously Kant, agree that we are talking about a right of visitation only. In Georg Cavallar's view, there is evolution here, and it is marked by the progressive 'thinning out' of the (cosmopolitan) concept of justice implied by hospitality, a justice which starts off thickly embedded in particular, natural law-based, accounts

${ }^{7}$ Ibid., p. 184 .

${ }^{8}$ Ibid., p. 185. See also Brain Tierney, The Idea of Natural Rights (Cambridge: Eerdmans, 1997), pp. 272 and $300-1$.

9 Pagden, 'Human Rights, Natural Rights', p. 186.

${ }^{10}$ Ibid., pp. 186-7; Martha Nussbaum, 'Kant and Stoic Cosmopolitanism', The Journal of Political Philosophy, 5:1 (1997), pp. 1-25.

11 Pagden, 'Human Rights, Natural Rights', p. 186. 
of hospitality and reaches its cosmopolitan 'climax' in Kant's 'thin conception of political justice'. ${ }^{12}$

There is a danger with reading hospitality in the natural law tradition in this way, or even in the other direction - as driven by the attempt to legitimate European appropriation. As Ian Hunter notes, whether read negatively as justifying colonialism or positively as containing the seeds of cosmopolitan ideals, 'critical' accounts of the law of nations in early modernity equally project a history of what this law 'should have been or could have become, as opposed to a history of what it contingently happened to be'. ${ }^{13}$ Critics on either side of the natural law debate thus share a metaphysical assumption 'that there is a global principle of justice capable of including European and non-European peoples within the "universal history" of its unfolding. ${ }^{14}$ Complementing these contextualising insights of intellectual history, the argument here is that, if there $i s$ a universal and enduring feature of the natural lawyers discourse on hospitality, then it takes the form of an absence rather than a presence - the repeated failure to finally stabilise the right to property with that of communication in hospitality. ${ }^{15}$ This is a tension that no theorist is able to resolve or even to contain precisely because, while property and communication constitute the possibility of hospitality, they also undermine one another.

Unlike contextual history, which limits itself to showing the local and particular in the so-called global and universal, such an analysis helps to explain a feature of international theory today - the invisibility of, or inattention to, hospitality that we find in it. It will be argued that it was precisely the inability of the natural lawyers to stabilise the terms of hospitality, the fact that it remained an enduring problem for them, that ensured its visibility. But with the stabilisation of the terms of hospitality, following either a Pufendorfian prioritisation of property (realists) or a Kantian lionisation of communication (idealists), hospitality ceases to be seen as at issue in the international, and drops out of sight accordingly. In other words, disciplinary IR's tendency towards one or the other pole of the binary of communication-property renders hospitality largely invisible. ${ }^{16}$ For realists, focused

12 Cavallar, The Rights of Strangers, p. 396.

13 Ian Hunter, 'Global Justice and Regional Metaphysics: On the Critical History of the Law of Nature and Nations', in S. Dorsett and I. Hunter (eds), Law and Politics in British Colonial Thought: Transpositions of Empire (Houndmills: Palgrave/Macmillan, 2010), p. 1.

14 Ibid., p. 2.

15 Although our thinkers assume, or so I argue, something like these two 'rights', I am not claiming that these are the terms in which they couch their own arguments on hospitality. 'Right of communication' and 'right of property' is rather my own reconstruction of the key terms of the natural lawyers' various discussions of hospitality, as I read them. This reconstruction is then directed towards deconstructive rather than historical understanding - that is, I seek to draw out paradoxes at the heart of the thought of hospitality rather than to add to our knowledge of how this thought has been differently articulated in diverse spatio-temporal contexts. This deconstructive reading does not claim that hospitality is a transhistorical concept, but rather that otherwise very different answers to the question of how to receive the stranger nonetheless share an inability to harmonise the 'communication' and 'property' that all talk of hospitality always already assumes. Thanks to an anonymous reviewer for encouraging me to clarify my point of departure.

${ }^{16}$ Within the discipline, though instructively not in its mainstream, three recent exceptions to this rule stand out: Roxanne Lynn Doty, 'Fronteras Compasivas and the Ethics of Unconditional Hospitality', Millennium, 35:1 (2006), pp. 53-74; Dan Bulley, 'Negotiating ethics: Campbell, ontopology and hospitality', Review of International Studies, 32:4 (2006), pp. 645-63; and Nicholas Onuf, 'Friendship and Hospitality: some conceptual preliminaries', Journal of International Political Theory, 5:1 (2009), pp. 1-21. 
on sovereign property, the fact that hospitality remains a significant norm and practice in IR (from international refugee and asylum law to summit meetings, state visits and exchange of diplomats) is simply overlooked. ${ }^{17}$ For idealists of the neo-Kantian variety, convinced of the transcendent role of global communication, the divisions of property (territory) in international politics are something to go beyond. But with this valorisation of communication over property, neo-Kantian discourse, following Kant himself, arguably anticipates a world politics without foreigners and thus without hospitality. This has been unremarked on in the literature to date, and the explanation for this must be that liberal cosmopolitan discourse is just as inattentive to the conditions of possibility of hospitality as realist discourse is to hospitality's effects. Given that hospitality, as welcome of the foreigner, is arguably the very principle of ethics itself, such neglect deserves to be overcome. $^{18}$

\section{Unstable hospitality: Vitoria and Vattel}

Given in 1539 at the University of Salamanca, Francisco de Vitoria's lectures On the American Indians engage the question of the rightful basis of Spanish dominion over 'these barbarians in the New World, commonly called Indians'. ${ }^{19}$ Vitoria argues in these lectures that the Indians have 'true dominion' over their goods and lands: first, because heretical beliefs do not invalidate ownership ('For the Lord maketh his sun to rise on the evil and on the good'); second, because the argument from de facto Spanish power would by extension imply that 'a robber would have right over other men'; and, third, because the barbarians 'are not in point of fact madmen, but have judgement like other men'. ${ }^{20}$ Vitoria also dismisses the argument for usurpation based on the Holy Roman Emperor being master of the world. 'Even those who attribute dominion of the whole world to the emperor', says Vitoria, 'do not claim that he has it by property, but only that he has it by jurisdiction. Such a right does not include the licence to turn whole countries to his own use [...]'. ${ }^{21}$ 'It is clear from all that I have said that the Spaniards, when they first sailed to the land of the barbarians, carried with them no right at all to occupy their countries'. ${ }^{22}$ Under the law of nations, only lands and goods which belong to no owner can pass to the occupier. Having established that the Indians have dominion, Vitoria is thereby able to state that their goods 'do not fall under this title'. ${ }^{23}$ The right to property is hereby universalised. Christian nations are not the only ones entitled to their domains; the Spanish are thereby guests in other people's homes.

In which case, by what right are the Spanish in the Americas at all given that they were not invited? The possible 'just titles' for Spanish colonisation that Vitoria

\footnotetext{
17 Onuf, 'Friendship and Hospitality' pp. 16-7.

18 Derrida, On Cosmopolitanism, p. 16 and Adieu, p. 50;

19 Francisco de Vitoria, Political Writings (Cambridge: Cambridge University Press, 1991), p. 233.

${ }^{20}$ Ibid., pp. 250, 243-6, 248, 250.

21 Ibid., p. 258.

22 Ibid., p. 264.

${ }^{23}$ Ibid., p. 265. For an extended discussion of Vitoria's account of property, see Tierney, The Idea of Natural Rights, pp. 260-4.
} 
considers start with that of 'natural partnership and communication', a precept of 'the law of nations' 'which either is natural law or derives from it'. ${ }^{24}$ Vitoria's right of hospitality here is constituted by a range of specific rights. These are, first, 'the right to travel and dwell in those countries, so long as they do no harm to the barbarians, and cannot be prevented by them from doing so'. ${ }^{25}$ Second, 'The Spaniards may lawfully trade among the barbarians, so long as they do no harm to their homeland. ${ }^{26}$ Third, "if there are any things among the barbarians which are held in common both by their own people and by strangers, it is not lawful for the barbarians to prohibit the Spaniards from sharing and enjoying them'. ${ }^{27}$ Fourth, 'if children born in the Indies of a Spanish father wish to become citizens (cives) of that community, they cannot be barred from citizenship or from the advantages enjoyed by the native citizens born of parents domiciled in that community'. ${ }^{28}$

Although Vitoria clearly has serious doubts about Spanish conduct and certainly does not claim unconditional rights for his compatriots, he thereby defends a right of hospitality. This right, if not unlimited, is perfect in the sense that it creates non-voluntary obligations on hosts - there is no communal right of inhospitality: 'to refuse to welcome strangers and foreigners is inherently evil'. ${ }^{29}$ It is worth considering in more detail Vitoria's attempt to rule out the possibility that the American Indians might justly close their doors to the Spanish. Vitoria starts by arguing that it is universally considered inhuman to 'treat strangers and travellers badly without some special cause, humane and dutiful to behave hospitably to strangers. This would not be the case if travellers were doing something evil by visiting foreign nations'. ${ }^{30}$ In addition, at the beginning of the world all was held in common; people could come and go as they pleased. The rise of nations in no way invalidates this original 'free mutual intercourse'. ${ }^{31}$ Besides, that which does no harm is lawful; therefore benign guests cannot lawfully be turned away. To banish a visitor is anyway tantamount to exile, which is considered a punishment for the most serious crimes. Indeed, to expel from or prevent entry to a territory is nothing less than an act of war, and 'the barbarians have no just war against the Spaniards, assuming they are doing no harm'. ${ }^{32}$ Bolstering his argument with classical, scriptural and ecclesiastical injunctions to hospitality, Vitoria concludes that 'the barbarians are obliged to love their neighbours [the Spanish] as themselves and may not lawfully bar them from their homeland without due cause'. ${ }^{33}$ As hospitality is thus a law of nature it is inalienable - any positive human law which sought to bar foreigners would simply be without foundation, 'without the force of law'. ${ }^{34}$ The right of hospitality may

${ }^{24}$ Ibid., p. 278. Vitoria singles out language and friendship as indicating that human beings are meant for social life. He of course cites Aristotle's zoon politikon on this point (Tierney, The Idea of Natural Rights, p. 291).

25 Vitoria, Political Writings, p. 278.

26 Ibid., p. 279.

27 Ibid., p. 280.

28 Ibid., p. 281.

29 Ibid., p. 281.

30 Ibid., p. 278.

31 Ibid., p. 278.

${ }^{32}$ Ibid.

${ }^{33}$ Ibid.

34 Ibid. 
therefore be enforced by Vitoria's compatriots if it is not upheld since anyone whose right has been infringed may justly resort to war.

In the context of the ongoing Spanish conquest of the Americas, the fact that Vitoria's right of hospitality is both a right to dwell and one that does not require the consent of the native inhabitants appears to place it squarely within a discourse legitimating colonial appropriation. Indeed, Vitoria's contemporary, Domingo de Soto, wondered why native Americans were constrained to offer hospitality to gold-mining Spaniards when 'neither can the French enter into Spain for the same purpose, nor can we enter France without the permission of the French'. ${ }^{35}$ One reason stands out: despite having undermined the right to property by emphasising a very extensive, indeed perfect, right of communication, Vitoria could not plausibly have applied this to relations between Europeans. Such unlimited hospitality could seem reasonable only in regard to Europeans as travellers to savage shores. In which case, as another of Vitoria's contemporaries, theologian Melchor Cano, put it, the problem become that the Spanish had no more gone to America as mere 'travellers' than had Alexander the Great on his sojourns; and 'We would not be prepared to describe Alexander the Great as a traveller.' 36

Though the right of communication is perfect and extensive in Vitorian hospitality, the parallel right to property, thin though it is, destabilises this right. The Indians have dominion over their lands even if they cannot claim exclusive property rights in them. Though the Spanish can stay indefinitely and help themselves to 'common' property such as gold in the ground, they are still 'guests' in some sense. Without going as far towards the pole of communication as Vitoria, this unresolved tension between right of communication and right of property in Vitorian hospitality is repeated later in the accounts given by Hugo Grotius and Emmerich de Vattel. In The Freedom of the Seas (1609), Grotius, despite universalising the right to property, continues to hold the Aristotelian notion of natural sociability and so makes hospitality a perfect - that is, enforceable right. ${ }^{37} \mathrm{He}$ thereby also sets in motion a profound indeterminacy between natural sociability and private property in hospitality. But it is in Vattel that we see this indeterminacy at its most obvious. In his Law of Nations (1758) Emmerich de Vattel devotes a chapter to 'Rules with Respect to Foreigners', specifying that he means to treat not foreign residents but 'only those foreigners who pass through or sojourn in a country, either on business, or as travellers' ${ }^{38}$ At the beginning of this chapter, Vattel states his intention for it, which includes drawing a distinction between the requirements of 'humanity and justice' and the 'rules of the law of nations' that would have made no sense to Vitoria:

the intention of this chapter is not so much to show what humanity and justice requires towards foreigners, as to establish the rules of the law of nations on the subject - rules

\footnotetext{
35 In Cavallar, The Rights of Strangers, p. 111.

${ }^{36}$ In Pagden, 'Human Rights, Natural Rights', p. 185. For more on the inhospitality of the conquistadores, see Gideon Baker, 'The Spectre of Montezuma: hospitality and haunting', Millennium, 39:1 (2010).

${ }^{37}$ Hugo Grotius, 'The Freedom of the Seas', in L. E. van Holk and C. G. Roelofsen (eds), Grotius Reader (The Hague: T. M. C. Asser Instituut, 1983 [1609]), pp. 11, 63-4, and 8-9 respectively.

${ }^{38}$ Emmerich de Vattel, The Law of Nations, trans. and ed. J. Chiity (New York: AMS Press, 1863 [1758]), p. 171.
} 
tending to secure the rights of all parties, and to prevent the repose of nations being disturbed by the quarrels of individuals. ${ }^{39}$

Vattel is quick to establish that property comes before hospitality: 'the lord of the territory may, whenever he thinks proper, forbid its being entered, he has, no doubt, a power to annex what conditions he pleases to the permission to enter. This [...] is a consequence of the right of domain. ${ }^{40}$ Yet Vattel immediately complicates this succinct statement of hospitality as an imperfect duty by then magnifying its importance: 'Can it be necessary to add, that the owner of the territory ought, in this instance, to respect the duties of humanity? ${ }^{41}$

Like the other natural lawyers, Vattel goes on to mention the inhospitality of the Chinese and Japanese without in any way condemning it; property or 'domain' trumps hospitality here. ${ }^{42}$ Yet Vattel directly thereafter cites Grotius to the contrary, agreeing with him that, given universal abhorrence at inhospitality, those tribes that treat strangers ill exclude themselves 'from the great society of mankind'. 'All other nations' thereby have 'a right to unite their forces in order to chastise them'. ${ }^{43}$ After Vitoria and Grotius, Vattel's account of hospitality is built upon a right of communication itself premised upon human sociability:

Being received in a foreign country, in virtue of the natural society, the communication, and commerce which nations are obliged to cultivate with each other, he [the travelling foreigner] ought to be considered there as a member of his own nation, and treated as such. ${ }^{44}$

Vattel also continues the scholastic theme of a primordial communism when 'men had, without distinction, a right to the use of every thing, as far as was necessary to the discharge of their natural obligations'. Against this backdrop, the introduction of 'domain and property' cannot have taken place without the following 'tacit restriction':

that every man should still preserve some right to the things subjected to property, in those cases where, without this right, he would remain absolutely deprived of the necessary use of things of this nature. This right is a necessary remnant of the primitive state of communion. ${ }^{45}$

From this it follows, Vattel reasons, that, 'notwithstanding the domain of nations', 'each nation still retains some right to what is possessed by others' in those things required for the fulfilment of their natural obligations. ${ }^{46}$ The 'right of passage' is one 'remnant' of this primitive state of communion, 'in which the entire earth was common to all mankind, and the passage was everywhere free to each individual according to his necessities. Nobody can be entirely deprived of this right'. ${ }^{47}$ 'The introduction of property cannot be supposed to have deprived nations of the general right of traversing the earth for the purposes of mutual intercourse, of carrying on commerce with each other, and for other just reasons. ${ }^{48}$

\footnotetext{
39 Ibid.

40 Ibid.

${ }^{41}$ Ibid.

42 Ibid.

43 Ibid., p. 173.

44 Ibid.

45 Ibid., p. 177.

46 Ibid., p. 1771.

47 Ibid., p. 179.

48 Ibid., p. 183.
} 
Kant would soon appear to build his account of a cosmopolitan right of hospitality on a near identical argument. Just as Kant's foreigner cannot be turned away if doing so will cause his destruction, so too for Vattel, 'Extreme necessity revives the primitive communion, the abolition of which ought to deprive no person of the necessities of life'; 'every man has a right to dwell somewhere upon earth' ${ }^{49}$ Also at one with Kant's understanding of cosmopolitan law as relating to rights (of hospitality) held by individual subjects in relation to foreign states, Vattel is clear that the right to the necessities of life 'belongs to individuals, when a foreign nation refuses them a just assistance'. But unlike Kant, whose right of hospitality is imperfect, Vattel retains the Vitorian (and Grotian) emphasis on the perfect right of guests to forcibly demand hospitality when it is denied them, though only in the case of necessity, a proviso absent in Vitoria given that right is always perfect for him. For Vattel, contra Vitoria, 'The right of innocent use', that right relating to the use of inexhaustible things such as rivers and ports, 'is not a perfect right, like that of necessity' and can be legitimately withheld by its owner. ${ }^{50}$ Notwithstanding this distinction, because the right of necessity is a perfect right, hospitality can still be forcibly taken, narrowing the gap between Vitoria and Vattel's accounts. Indeed, in the following passage, and despite his earlier assurance that 'the lord of the territory may, whenever he thinks proper, forbid its being entered', necessity makes a perfect right of hospitality where European travellers are concerned:

Captain Bontekoe, a Dutchman, having lost his vessel at sea, escaped in his boat, with a part of his crew, and landed on an Indian coast, where the barbarous inhabitants refusing him provisions, the Dutch obtained them sword in hand. ${ }^{51}$

Is Vattel being 'Eurocentric' here, or is it because his discourse is casuistical that he refuses to accept that principles such as hospitality apply uniformly in all circumstances? And, in the case of Captain Bontekoe, the travellers, regardless of their being European, find themselves in extremis. Whether expressed by way of casuistry or not, we are beginning to see a tension running through Vattel's entire argument, and is not much helped by the distinction between perfect and imperfect right. Though nobody can be 'entirely deprived' of the primitive right of passage, though the exercise of such a right is only 'limited', not abrogated, by the introduction of domain and property', yet, on the other hand, 'The effect of property is, to give the proprietor's advantage a preference over that of all others. ${ }^{, 52} \mathrm{He}$ is 'bound to grant a passage for lawful purposes' only 'whenever he can do it without inconvenience to himself'. ${ }^{53}$ Yet this apparent resolution in favour of property over hospitality is repeatedly undermined: when refused admission to a territory by its owner, 'forcing a passage', is still rightful 'in spite of him' if one has 'some reason more cogent than all his reasons to the contrary. Such is the right of necessity. ${ }^{54}$ At this point, like Vitoria, Vattel appears to leave the final judgement on when hospitality can legitimately be denied up to the guest to determine. The implication that Europeans can continue to be the arbiters of

\footnotetext{
${ }^{49}$ Ibid., pp. 178, 180.

50 Ibid., p. 181.

51 Ibid., p. 178.

52 Ibid., p. 179.

53 Ibid., p. 183.

${ }^{54}$ Ibid., pp. 179-80.
} 
their own reception might also be thought the same as in Vitoria, except that, unlike Vitoria, Vattel is at this point discussing 'rights which belong to all nations' rather than rights which Europeans have in the Americas. Furthermore, another example that Vattel gives in order to clarify his discussion appears to give the final trump card to the host community when self-preservation is at stake:

Thus, a vessel driven by stress of weather has a right to enter, even by force, into a foreign port. But, if the vessel is affected with the plague, the owner of the port may fire upon it and beat it off, without any violation either of justice or even of charity, which, in such a case, ought doubtless to begin at home. ${ }^{55}$

However understandable this course of action, it would still have constituted a violation of natural law for Vitoria. Vattel's right of passage is ultimately less stringent, not to mention much less extensive, than Vitoria's right of hospitality. ${ }^{56}$

In the end, and despite the undoubted subtlety and flexibility of his casuistical method, Vattel cannot allow himself to let hospitality undermine property. In concluding his discussion of the 'rights which belong to all nations', 'it is the nation in whom the property is vested that is to determine whether the use which others wish to make of what belongs to her be really innocent [...] The domain gives only the right of judging, in particular cases, whether the use be really innocent. ${ }^{57}$ While the right of necessity can be utilised by the unwelcome guest in extremis (and, perhaps instructively, Vattel's only example of this right in operation relates to Europeans in the Indies), the right of hospitality is for the host to judge and his obligation is a matter of conscience only:

In explaining the effects of domain we have said above that the owner of the territory may forbid the entrance into it, or permit it on such conditions as he thinks proper. We were then treating of his external right, - that which foreigners are bound to respect. But now that we are considering the matter in another view, and as it relates to his duties and to his internal right, we may venture to assert that he cannot, without particular and important reasons, refuse permission, either to pass through or reside in the country, to foreigners who desire it for lawful purposes. For, their passage or their residence being in this case an innocent advantage, the law of nature does not give him a right to refuse it: and, though other nations and other men in general are obliged to submit to his judgement, he does not the less offend against his duty, if he refuses without sufficient reason: he then acts without any true right; he only abuses his external right. ${ }^{58}$

There is a natural law of hospitality here, but it is for states to decide when and how it operates. Hospitality as an imperfect right is transformed into the gift of the sovereign. ${ }^{59}$ And yet, while the sovereign himself cannot ultimately be bound by the law of hospitality, every hospitable citizen 'discharges his duty to mankind, while at the same time render[ing] essential services to his country'. ${ }^{60}$ Vattel's assumption seems to be that hospitality can unite twin duties to humanity and nation, but, on the basis of the manifest indeterminacy of his own cases, we might fairly say that this optimism seems misplaced. Like Vitoria and Grotius before him,

\footnotetext{
55 Ibid., p. 180.

56 This tension between property and communication continues in Vattel's discussion of rights of shelter held by exiled and banished peoples (see ibid., p. 180).

57 Ibid., p. 182.

58 Ibid., p. 184.

${ }^{59}$ See, for example, ibid., p. 185

${ }^{60}$ Ibid., pp. 185-6.
} 
Vattel ultimately cannot decide between right of communication and right of property in hospitality.

\section{The stabilisation of hospitality via property: Pufendorf}

Samuel von Pufendorf is notable as the first of the natural lawyers to stress the right of any community to refuse visitors. As Pufendorf writes in The Law of Nature and Nations (1672), though we ought to offer hospitality where it will do us no harm, 'Reason forbids that any one should raise a lasting Structure or Edifice [...] without express Allowance from the Sovereign'. ${ }^{61}$ Against the tendency of the Ancients to elevate the 'Right of Hospitality' to the 'most sacred Friendship', hospitality obligates only if 'the Stranger be absent from his own House on an honest, or on a necessary Account; as also that we have no Objection against his Integrity, or Character, which might render our Admission of him, either damaging or disgraceful':

Now although Inhospitality be commonly, and for the most part justly censured as the true Mark of a savage and inhuman Temper, yet the Point will now and then bear a dispute, especially as to the Case of those who wander into foreign countries purely on account of Curiosity. ${ }^{62}$

Pufendorf seeks to move international hospitality from a perfect to an imperfect duty analogous to friendship - while it may be desirable, it is not enforceable, no right comes attached to it: ${ }^{63}$

The Duties here meant, by such as could not have been extorted by Force or Law, are such as are not absolutely necessary for the Preservation of Mankind, and for the Support of Human Society in general, although they serve to embellish it, and render it more commodious. Such are the Duties of Compassion, Liberality, Beneficence, Gratitude, Hospitality, and in one word all that is contain'd under that comprehensive Name of Charity, or Humanity, as it is oppos'd to rigorous Justice properly so call'd, the Duties of which, generally speaking, have their Foundation in Agreement. ${ }^{64}$

Hospitality, for Pufendorf, is charity, and charity can of course be refused. The agreement of Vitoria and Grotius on a right of international hospitality (the former in the name of mission, the latter in the name of trade) of course ruled out such a right of refusal - though guests should be hospitable in not appropriating the homes of their hosts, no host has the right to close his door. The bases of Pufendorf's 'right' of communal inhospitality do not issue in his concern for colonial appropriation, of course, but rather in the break from the old (Aristotelian) school's search for the good in the nature of things brought about by his attempt to restrict or 'de-transcendentalise' natural law by limiting it to the positive laws of a territorial sovereign. ${ }^{65}$ Only by containing law within spatial boundaries - namely,

${ }^{61}$ Samuel von Pufendorf, On the Law of Nature and Nations, trans. B. Kennett, ed. Barbeyrac (Clark, NJ: The Lawbook Exchange, 2005 [1672]), p. 244.

62 Ibid.

${ }^{63}$ Cavallar, The Rights of Strangers, p. 201.

${ }^{64}$ Samuel von Pufendorf, The Whole Duty of Man, According to the Law of Nature, trans. A. Tooke, ed. I. Hunter and D. Saunders (Indianapolis: Liberty Fund, 2003 [1691]), p. 50n.

${ }^{65}$ Martti Koskenniemi, 'Miserable Comforters: International Relations as New Natural Law', European Journal of International Realtions, 15:3 (2009), p. 397; Ian Hunter, 'Spatialisations of Justice in the Law of Nature and Nations: Pufendorf, Vattel and Kant', unpublished research paper, 
by denying that the law of nations has the status of law at all - can the destabilising effects of trans-territorial allegiances (especially religious affiliations given their key role in the civil and international conflicts of Pufendorf's time) be brought under control. This hardening of the meaning of sovereignty in Pufendorf is echoed in his treatment of property. Like the other natural lawyers, in The Whole Duty of Man (1691) Pufendorf held that, originally, there was common dominion and that property is established first by use but otherwise remains in common. ${ }^{66}$ But unlike Grotius, who he defines himself against on this point, Pufendorf does not believe that, following the establishment of private property, this right of common use revives under dire necessity. This would undermine both the security of property and the ability of property holders to differentiate between deserving and undeserving cases. Perhaps most importantly, a revival of the natural right to common property in the case of necessity would remove the opportunity for property holders to show mercy to the needy and for the needy to respond with gratitude. ${ }^{67}$ After all, ownership was established, on the one hand, in order to provide the owner with the opportunity to show largesse to others and thereby put them under obligation to him. On the other hand, 'all this Merit and Obligation is cut off, when we give another only what he might otherwise, as his Right and Due, violently taken from us' ${ }^{68}$ Humanitarian duty and the right to common property in extremis are, for Pufendorf, incompatible. The implication of Pufendorf's account of property for hospitality is therefore the same as his account of sovereignty: on both accounts hospitality shifts from being a right held by travellers in need of shelter to a compassionate duty owed by hosts. No longer a part of the natural law, hospitality becomes, with Pufendorf, a humanitarian duty.

Pufendorf also revises Grotius' neo-scholastic account of human sociability. Pufendorf does not see sociability as a natural disposition but rather as a moral duty to achieve civil peace in the context of a quite unsociable state of nature. '[T]his is a fundamental Law of Nature, That EVERY MAN OUGHT, AS MUCH AS IN HIM LIES, TO PRESERVE AND PROMOTE SOCIETY: That is, the Welfare of Mankind". ${ }^{69}$ Attending to the welfare of mankind requires us to go beyond the no-harm principle in conferring positive benefits where so doing will not harm us in any way. 'That every Man ought to promote the Good of another, as far as conveniently he may' is in order that in mutually communicating good offices to others, 'common brotherly Love may be kept up among Men' ${ }^{70}$ Such sociability requires, first, following Virgil and Grotius, 'the liberty of Sailors, to touch and to rest a little on any shore'; second, 'the admission of Strangers, and the kind Reception and Entertainment of Travellers'; and, third, after Grotius, 'the allowing of a perpetual Habitation to Strangers, who being driven by Violence out of their own Country, are forced to seek out a new Seat' (as long as they submit to their new sovereign, that is). ${ }^{71}$ Just as the humanitarian kindness shown by benefactors and the gratitude shown in return form the social bonds that dampen

available at: UQ e-space $\{$ http://espace.library.uq.edu.au/\}, p. 23.

${ }^{66}$ Pufendorf, The Whole Duty of Man, pp. 128-32.

${ }^{67}$ John Salter, 'Grotius and Pufendorf on the Right of Necessity', History of Political Thought, 26:2 (2005), pp. 284-302.

68 Pufendorf, On the Law of Nature and Nations, p. 208.

${ }^{69}$ Pufendorf, The Whole Duty of Man, p. 56.

70 Ibid., p. 104.

71 Pufendorf, On the Law of Nature and Nations, pp. 243-5. 
our natural (Hobbesian) disputatiousness, ties which would be quite impossible without the introduction of private ownership, so too, it seems, the pacifying ties of international hospitality for Pufendorf are born of the hierarchy of host and guest which is first established by the host's ownership. ${ }^{72}$

This host- rather than guest-centric framing of hospitality makes it obvious to Pufendorf that:

supposing that any one Nation, contented with what it finds at home, utterly refrains from foreign Travel, it does not appear what Obligation such a State can have to admit those who would visit it, without a necessary or weighty Cause. ${ }^{73}$

Even non-European societies that fail Pufendorf's European standards of statehood have this right of closure extended to them. Like Gentili before and Kant after him, Pufendorf endorsed Chinese isolationism in this regard. ${ }^{74}$ Equally, Spanish hospitality rights in the Americas as defended by Vitoria are rejected for mistakenly prioritising 'natural partnership and communication' over rights of ownership. Europeans have no right to visit and dwell (nor trade) with other peoples any more than the reverse. Large numbers of guests may anyway conflict with the sovereign's duty of protection of his subjects as established in natural law:

this natural Communication [of Vitoria's] does not hinder a just Proprietor from communicating his Goods by such Methods, and upon such Considerations as he finds necessary. And further, that it seems very gross and absurd, to allow others an indefinite or unlimited Right of travelling and living amongst us, without reflecting either on their Number, or on the Design of their coming. ${ }^{75}$

Vitoria's claim that, 'If the Indians had amongst them any Rights and Privileges allow'd in common to natives and Foreigners, in these they ought not to hinder the Spaniards from their Share', is also rejected on the grounds that it is within the rightful gift of property holders to be 'more liberal to one than to another' just as the owner of a garden may grant special privileges to one neighbour over another. ${ }^{76}$ Although Pufendorf does not, as Diderot and Kant do, use inhospitality explicitly to condemn European conquest, for Cavallar, his insistence that foreign states may only intervene: first, on behalf of their own citizens; second, when these citizens are harmed, and; third, when they have arrived as innocent guests or driven by storms', implicitly allows for the same. ${ }^{77}$ However, as Cavallar also notes, Pufendorf's interest in non-European affairs is limited and his examples are mostly taken from classical antiquity. We should not read into his defence of sovereign closure a critique of European colonialism but rather see in it the reordering of natural law in which, contra the schoolmen, 'the People's Safety is the supreme Law' which the sovereign must enact in positive law. ${ }^{78}$

Counterpoised to his sovereign right of communal inhospitality, Pufendorf continues to insist that hospitality expresses moral obligations to foreigners: it is barbarous to treat in the same cruel manner, those who visit us as Friends, and

72 Salter, 'Grotius and Pufendorf', p. 297.

73 Pufendorf, On the Law of Nature and Nations, p. 245.

${ }^{74}$ Cavallar, The Rights of Strangers, p. 204.

75 Pufendorf, On the Law of Nature and Nations, p. 245; see also p. 246.

76 Ibid., p. 245.

77 Cavallar, The Rights of Strangers, pp. 206-7.

${ }_{78}$ Pufendorf, On the Law of Nature and Nations, p. 739. 
those who assault us as Enemies' ${ }^{79}$ But is hospitality really reducible to the moral virtue of the host? At the limits of his account, Pufendorf seems to allow for the rights of guests too - acknowledging that, finding himself in extreme necessity, the shipwrecked traveller may 'forcibly' 'relieve himself' out of the abundance of his host. ${ }^{80}$ Elsewhere, Pufendorf summarises this right of necessity thus:

in case of extreme Necessity, the Imperfect Right that others have to the Duty of Charity from us, becomes a Perfect Right; so that Men may by force be obliged to the performance of these Duties at such a time $[\ldots]^{81}$

What are we to make of this seeming collapse of imperfect right back into perfect right in the case of extreme necessity? Does it destabilise the entire edifice of perfect-imperfect right which, as Cavallar sees it, enables Pufendorf to be the first to find a solution to the problem of hospitality as set out in the natural law tradition since Vitoria? ${ }^{82}$ For Cavallar, by distinguishing between the realm of love of humanity and rights, and consigning hospitality to the former, Pufendorf is able to avoid many of the inconsistencies that dogged former accounts of hospitality rights under the law of nations. But does Pufendorf's inclusion of a right of necessity fatally undermine this achievement? In the final analysis, probably not; Cavallar is no doubt correct that this right does not shift the overall direction of Pufendorf's argument: 'communities have a perfect right to refuse visitors'. ${ }^{83}$ Cases of exception owing to extreme exigency ('the law of necessity') are classic instances of casuistical reasoning, drawn from the theological tradition (for example, it is wrong to steal but not necessarily during a famine) ${ }^{84}$ Although he broke so decisively with the scholastics who practiced it, this flexibility in application of first principles characteristic of casuistry is likely still at work in Pufendorf's account of a right of necessity for the shipwrecked (as it probably was, later still, in the work of Vattel as we saw above). ${ }^{85}$ Besides, in general, perfect right only exists for Pufendorf within a civil condition under a sovereign because rights are wholly dependent on obligation and obligation only exists where there is a superior capable of issuing coercive laws with 'just cause' for doing so.

Yet we should note, along with Cavallar, that the price paid for this conceptual stability, for this construction, is that hospitality becomes a host-centric category and, in this sense, Pufendorf can be read as anticipating the demise of the law of hospitality:

As to our main Question [regarding hospitality rights], it is look'd on by most as the safest way of resolving it, to say, That it is left in the power of all States, to take such Measures about the Admission of Strangers, as they think convenient. ${ }^{86}$

79 Ibid., p. 245.

${ }^{80}$ Ibid., p. 207.

${ }^{81}$ Pufendorf, The Whole Duty of Man, p. 50n.

${ }^{82}$ Cavallar, The Rights of Strangers, p. 205. In the case of the necessitous poor under civil law, Salter ('Grotius and Pufendorf') argues that Pufendorf's right of necessity does undermine the coherence of his distinction between perfect and imperfect right. But we are considering international law here, where, for Pufendorf, things are clearly very different.

${ }^{83}$ Cavallar, The Rights of Strangers, p. 204.

${ }^{84}$ Thanks to Ian Hunter for drawing this to my attention.

85 Though see Koskenniemi ('Miserable Comforters', p. 399) for an opposing view here.

${ }^{86}$ Pufendorf, On the Law of Nature and Nations, p. 245; see also p. 246. 
To the extent that he does manage to stabilise his account of hospitality, Pufendorf does so in the name of property. The ties of obligation and gratitude that bind the wealthy and the poor domestically also link hosts and guests internationally; both thus serve to pacify the otherwise fractious state of nature which obtains both in the absence of the sovereign and between sovereigns, a state Pufendorf came to believe in via his reading of Hobbes. But though it may be nobly humanitarian, as charity hospitality can no longer function as a law of nature and nor did Pufendorf want it to.

\section{The stabilisation of hospitality via communication: Kant}

Kant's Third Article of Perpetual Peace (1795) states that 'The Law of World Citizenship Shall be Limited to Conditions of Universal Hospitality'. Echoing the right of communication upheld from Vitoria onwards, Kant's cosmopolitan right of hospitality as laid out in Perpetual Peace entails a 'right of resort' or visitation. This amounts to a right to offer oneself for exchange or community, a communicative offer which Kant appears not to want to limit given that his phraseology covers cultural and economic exchange as well as civil association. ${ }^{87}$ Identifying hospitality with communicative rights also makes sense in the context of Kant's wider communicative claims to freedom of expression in Metaphysics of Morals and to the 'freedom of the pen' in Theory and Practice. A subjective cosmopolitan right to hospitality therefore appears to complement these other two subjective rights to communication which are, respectively, human and civil rights. ${ }^{88}$

While the 'right of strangers' allows foreigners to 'attempt to enter into relations with the native inhabitants', the 'right of a guest to be entertained' requires a 'special friendly agreement' that cannot be the subject of universal right. ${ }^{89}$ This right of host communities to refuse hospitality if by so doing they do not threaten the destruction of their guest is the subject of intense debate, though it is hardly a dilemma new to Kant, as we have seen. While Derrida in particular has chosen to read this limitation as but one chapter in a long story of European inhospitality towards guests, we might see it rather as an attempt to extricate a cosmopolitan right of hospitality from European justifications for colonialism given the: ${ }^{90}$

inhospitable conduct of the civilized states of our continent, especially the commercial states, the injustice which they display in visiting foreign countries and peoples (which in their case is the same as conquering them) seems appallingly great. ${ }^{91}$

${ }^{87}$ Peter Niesen, 'Colonialism and Hospitality', Politics and Ethics Review, 3:1 (2007), p. 92.

${ }^{88}$ Niesen, 'Colonialism and Hospitality', p. 92.

${ }^{89}$ Immanuel Kant, 'Perpetual Peace: A Philosophical Sketch', in Kant: Political Writings, trans. H. B. Nisbet and ed. H.S. Reiss (Cambridge: Cambridge University Press, 1991), p. 106.

${ }^{90}$ See Derrida, Adieu, p. 68; Derrida, Of Hospitality, pp. 27 and 71-3; Jacques Derrida, 'Hostipitality', Angelaki, 5:3 (2000), pp. 3-4; Derrida: On Cosmopolitanism, pp 11, 22 and 27. For a contrary view, see Garrett W. Brown, 'The Laws of Hospitality, Asylum Seekers and Cosmopolitan Right: a Kantian response to Jacques Derrida', European Journal of Political Theory, 9:1 (2010).

91 Kant, 'Perpetual Peace', p. 106. 
For Niesen, there is, first, a systematic reason for Kant's treating colonialism under cosmopolitan law. This is that Kant had already defined international law as the law of nations, such that relations between states and non-state peoples could not be covered by it. Unlike states, non-state peoples are not protected by Kant's international law against intervention. ${ }^{92}$ Cosmopolitan law has to make good on this lack. Second, argues Niesen (and this point is especially important for our discussion here), Kant must have realised that his own doctrine of private law, unless limited by a higher cosmopolitan law (namely, the limits of hospitality), could easily legitimate colonial appropriation given the steps it makes from private law to rights to set up a civil condition or state. This is that Kant argues in Metaphysics of Morals for rightful, if provisional, appropriation of unowned objects in the state of nature (since such appropriation must by definition be unilateral) and marries this to a right to coerce all neighbours who might dispute my property claims into a civil condition (since otherwise there can be no hope of anyone agreeing to respect my ownership arrived at in this unilateral way). ${ }^{93}$ Only by such an imperfect process, Kant reasons, might public law finally regulate property rights rightly. But, as an unintended consequence of this logic, the claim of settlers to presumptively unowned territory could, on Kant's private law terms should, move easily from colonial trading post to the full political domination of native inhabitants: just 'one claim to private possession of one object is both necessary and sufficient to unleash a state-building development that must not be stopped until a general determination of property rights in a civil condition has been achieved'. ${ }^{94}$ In this context, Kant's prohibition, also in Metaphysics of Morals, of any right of colonialists to establish civil settlements by violence, may be instructive. ${ }^{95}$ Kant appears to be denying that the dynamic of property appropriation can legitimately by coercively introduced by outsiders even if a 'state of nature' prevails there, and perhaps introduces his limitation on the law of hospitality for this very purpose. ${ }^{96}$

Niesen's argument is that if Kant did not intend thus to neutralise private law as a driver of colonial appropriation by limiting cosmopolitan hospitality, then how else are we to understand his, otherwise puzzling, endorsement of Japanese and Chinese isolationism? Niesen suggests that the largely overlooked contradiction in Perpetual Peace between hospitality as a 'right to visit' and the fact that Kant seems quite happy with Chinese and Japanese wholesale restrictions on visitation (both of their own citizens and foreigners) can only be explained if we see that Kant envisages restrictions on attempts at communication of the commercial kind: only communicative offers of a non-economic nature are protected under cosmopolitan law. ${ }^{97}$ If Kant had intended cosmopolitan hospitality as a right to free trade, as many assume, ${ }^{98}$ then surely China and Japan's stance would have been objectionable to him?

92 Niesen, 'Colonialism and Hospitality', p. 94.

93 Immanuel Kant, 'The Metaphysics of Morals', in Kant: Political Writings, trans. H. B. Nisbet and ed. H. S. Reiss (Cambridge: Cambridge University Press, 1991), p. 138.

${ }^{94}$ Niesen, 'Colonialism and Hospitality', p. 94.

95 Kant, 'The Metaphysics of Morals', pp. 172-3.

${ }^{96}$ Niesen, 'Colonialism and Hospitality', p. 95.

97 Ibid., pp. 98-100.

${ }^{98}$ See, for example, Seyla Benhabib, The Rights of Others: Aliens, Residents and Citizens (Cambridge: Cambridge University Press, 2004), p. 38. 
How does Kant arrive at his right of hospitality? Again, there has been significant recent debate surrounding this issue. For Kleingeld, Kant's innate human right to external freedom implies hospitality, since the former entails both a right of communication and a right to be wherever nature or chance has determined. ${ }^{99}$ Benhabib follows suit in making a strong connection between the innate human right to freedom in Kant and his right of cosmopolitan hospitality. ${ }^{100}$ Kant certainly seems to argue along these lines, stating in Metaphysics of Morals that, if even only one of these three possible forms of rightful state [the civil, international and cosmopolitan] lacks a principle which limits external freedom by means of laws, the structure for all the rest must inevitably be undermined, and finally collapse'. ${ }^{101}$ Yet Niesen is not so sure that this argument alone will suffice, pointing out that the strategy of deriving hospitality from innate external freedom appears to restrict hospitality to the involuntary contact characteristic of the shipwrecked. ${ }^{102}$ The argument from nature or chance in the determination of one's whereabouts, in short, does not work for voluntary contact. While this might not be a problem for Benhabib, given her focus on the desperate and dispossessed seeking asylum, Kant's idea of hospitality is one of a much more expansive global communication and, moreover, of a right of communication, in which case voluntary contact seems just as important to it. ${ }^{103}$

The rational idea, as discussed above, of a peaceful (if not exactly amicable) international community of all those of the earth's peoples who can enter into active relations with one another, is not a philanthropic principle of ethics, but a principle of right. Through the spherical shape of the planet they inhabit (globus terraqueus), nature has confined them all within an area of definite limits. Accordingly, the only conceivable way in which anyone can posses habitable land on earth is by possessing a part within a determinate whole in which everyone has an original right to share. Thus all nations are originally members of a community of the land. But this is not a legal community of possession (communio) and utilisation of the land, nor a community of ownership. It is community of reciprocal action (commercium), which is physically possible, and each member of it accordingly has constant relations with all the others. Each may offer to have commerce with the rest, and they all have a right to make such overtures without being treated by foreigners as enemies. This right, insofar as it affords the prospect that all nations may unite for the purpose of creating certain universal laws to regulate the intercourse they may have with one another, may be termed cosmopolitan (ius cosmopoliticum). ${ }^{104}$

To Niesen's mind, following Flikschuh, Kant's argument in the Metaphysics of Morals from the 'original community of land' is a much surer ground for hospitality than innate rights since it enables the claim that unilateral acquisition, rather than nature or 'right', 'obligates individuals and nations towards each other'. ${ }^{105}$ Given the unilateral quality of property acquisition, such appropriation remains provisional prior to the establishment, not only of a domestic civil

\footnotetext{
99 Pauline Kleingeld, 'Kant's Cosmopolitan Law', Kantian Review, 2:1 (1998), pp. 73-90.

${ }^{100}$ Benhabib, The Rights of Others. See also, Sharon Anderson-Gold, Cosmopolitanism and Human Rights (Cardiff: University of Wales Press, 2001).

${ }^{101}$ Kant, 'The Metaphysics of Morals', p. 137.

102 Niesen, 'Colonialism and Hospitality', p. 101.

103 Ibid., p. 102.

${ }^{104}$ Kant, 'The Metaphysics of Morals', p. 172.

${ }^{105}$ Niesen, 'Colonialism and Hospitality', p. 102. Katrin Flikschuh, Kant and Modern Political Philosophy (Cambridge: Cambridge University Press, 2000), p. 141. See also, Sankar Muthu, 'Justice and Foreigners: Kant's Cosmopolitan Right', Constellations, 7:1 (2000), pp. 34-5.
} 
condition, but also, by extension (given original 'possession in common'), to the founding of no less than a cosmopolitan constitution by which existing ownership might finally be ratified or rectified. ${ }^{106}$ Unlike the argument from right, working from the fact of appropriation allows a cosmopolitan legal order to be implied by human actions (unilateral acquisition) rather than 'nature'. Such cosmopolitan right, rather than being an abstract property of humanity as such, is mediated by membership of particular political communities - it is precisely our membership of communities constituted by, or dispossessed by, acts of appropriation that then provides us with duties and rights of hospitality respectively. ${ }^{107}$

Put more generally, hospitality thus obligates those who stay at home as much as those who travel abroad since my contingent act of appropriation of a native soil is as much a background condition of the traveller's homelessness as is his travel. Everybody, both at home and aboard, is affected by territorial ownership and this ownership has yet to be redeemed in a global civil condition. Until that day, 'The final justification of hospitality would then lie in the responsibility of cosmopolitan citizens to change that structure towards permanent justifiable relations of property distribution.' ${ }^{108}$ This is perhaps why Kant writes of the right of hospitality in Perpetual Peace as 'the right of a stranger', since, sharing original ownership with us, the foreigner has a certain residual right to our territory, an authority which is expressed in the limited right of hospitality he has in it: 'for all men are entitled to present themselves in the society of others by virtue of their right to communal possession of the earth's surface'. ${ }^{109}$ Kantian cosmopolitan hospitality thereby moves from being a justification for global trade to something much more radical: 'the (re)distribution of property claims'. ${ }^{110}$ On such a reading, one of Derrida's critiques of Kant's right of hospitality - that it presupposes the place of welcome - misses the mark. ${ }^{111}$ For Niesen and Flikshcuch, Kantian hospitality stands as a limit on property holdings in the sense that it both recognises their provisional nature in the absence of a global civil settlement and provides the conditions (global communication) by which such a settlement might come about.

From a very different perspective on Kant's political writings, Hunter has also argued that Kant's account of rightful appropriation of the earth's surface (property, in our terms here) is provided by his notion of universal communication in a 'perfect civil union of the human race'. ${ }^{112}$ Hunter's case, however, is that this is because Kant's metaphysics, upon which his political essays are super-structural, makes this order of priority (communication first, property second) necessarily so. Hunter argues that, though it makes no explicit appearance in them, Kant's three

${ }^{106}$ Niesen extends Flikschuh's 'unilateral appropriation' to include 'colonial usurpation'. Unlike the former, the latter is not even in principle ratifiable in a global civil constitution and will instead have to be rectified.

${ }^{107}$ Niesen, 'Colonialism and Hospitality', p. 103; Garrett W. Brown, 'Kantian Cosmopolitan Law and the Idea of a Cosmopolitan Constitution', History of Political Thought, 27:4 (2006), p. 664; Flikschuh, Kant and Modern Political Philosophy.

${ }^{108}$ Niesen, 'Colonialism and Hospitality', p. 103.

${ }^{109}$ Kant, 'Perpetual Peace', p. 106.

${ }^{110}$ Niesen, 'Colonialism and Hospitality', p. 105; cf. F. H. Hinsley, Power and the Pursuit of Peace (Cambridge: Cambridge University Press, 1963).

111 Derrida, 'Hostipitality', p. 4.

${ }^{112}$ Hunter, 'Kant's Cosmopolitanism from a Historical Viewpoint', in B. Hindess and R. B. J. Walker (eds), The Cost of Kant, forthcoming. 
essays on cosmopolitan peace (Universal History, Theory and Practice and Perpetual Peace) are underlined by a central theme of his highly esoteric metaphysics: the question of "how a universe of intelligible beings ("pure intelligences") can form a legal community, understood as a community formed for the rightful possession of an external world of things'. ${ }^{113}$ Kant's answer to this question is given by the notion that 'relations of reciprocal coercion permit the free choices of each to be reconciled with the free choices of all in a common will'. This principle then forms the basis of Kant's famous 'universal principle of right', namely that 'Any action is right if it can coexist with everyone's freedom in accordance with a universal law. ${ }^{114}$ Without the rightful possession of things being conceived as the reciprocal possession that intelligible beings exercise over each other's wills, possession would be reduced to the physical attachment of these beings to material things in time and space. This would be incompatible with Kant's metaphysics by which intelligible beings are spontaneously capable of conforming their wills to and through pure thought rather than having their wills constrained by dependence on corporeal things. 'Were (property) right to be based on the physical possession of things in space, it would destroy the pure reciprocity of willing that permits the pure intelligences to possess things "rightfully" - that is, non-spatially or noumenally - as members of a spiritual or intellectual world.'115 As Kant puts it:

Wherever power reaches, freedom can be limited not through nature and the conditions of possession that lie in it, but only through and from agreement with the freedom of others [...] The common will is thus the condition of all acquisition and of that which is mine and thine in general. ${ }^{116}$

For Kant, then, right or justice is necessarily cosmopolitan; territorial forms of right are merely the hurdles that the dialectic of history has placed in the way of the achievement of (noumenal) universal community in the phenomenal world. ${ }^{117}$ Starting with empirical possession as Kant's 'sorry comforters' do, we are incapable of seeing "the purely "intellectual" relations among "pure intelligences" that makes external possession possible'. ${ }^{118}$ Indeed, even Kant's seeming agreement with the other natural lawyers on originary common possession of the earth is treated in his Rechtslehre 'as an analogy supplied by nature for the ideal unity of wills that would make this taking-possession rightfully possible'. ${ }^{119}$ While for the natural lawyers original collective ownership is a primordial right which only survives in some modified form (hence the right of hospitality), for Kant it points us towards a future right that it only anticipates. Rather than trying to derive rightful possession from empirical possession, originary or not, Kant suggests in Critique of Practical Reason that 'the opposite procedure is followed and all the conditions of intuition that ground empirical possession must be removed (abstracted from) in order to extend the concept beyond empirical possession'. ${ }^{120}$

\footnotetext{
113 Ibid., p. 10.

${ }^{114}$ Immanuel Kant, 'Critique of Practical Reason', in trans. and ed. M. J. Gregor Practical Philosophy (Cambridge: Cambridge University Press, 1996), p. 230.

${ }^{115}$ Hunter, 'Kant's Cosmopolitanism from a Historical Viewpoint', p. 17.

${ }^{116}$ Kant, in ibid., p. 17.

${ }^{117}$ Hunter, 'Kant's Cosmopolitanism from a Historical Viewpoint', p. 11.

${ }^{118}$ Ibid., p. 21.

${ }^{119}$ Ibid., p. 23.

${ }^{120}$ Kant, 'Critique of Practical Reason', p. 252.
} 
Kant's doctrine of right thereby treats 'the synthetic dimension of this doctrine (empirical possession of the earth's surface) as the product of the analytic or $a$ priori dimension (the unity of intelligible wills)'. It is thus not empirical common possession of the earth which justifies the idea of the common will. 'Rather, by treating it as a pure duty to be acted on, [Kant] views the a priori idea of a common will as something that transcends empirical possession. ${ }^{121}$ Communication comes decisively before property and this drives Kant's political thought towards necessarily cosmopolitan conclusions:

In deriving the concept of right from transcendental recollection of twin inborn ideas - of the original common possession of the earth, and the a priori general will that effects its rightful distribution - Kant is compelled to conceive the juridical-political order in cosmic terms $[\ldots$ T] he concept of a political territory is incapable of formulation within the core concepts of Kant's legal metaphysics. So too the only legitimate source of juridical and political authority for Kant is the reciprocally unified common willing of a universal community of pure intelligences formed through their occupancy of the globe. ${ }^{122}$

As Hunter notes, putting Kant's anxieties about the prospect of colonial expansion in the context of his wider thought, despite acknowledging that the issue of the territorial aspect of the empirical acquisition of the earth is the 'hardest of all to solve', Kant continues to insist that if it is to be fully rightful, then the scope of original acquisition must become cosmopolitan: 'But even if it is solved through the original contract, such acquisition will always remain only provisional unless this contract extends to the entire human race." 23 The significant implication of this insight for our study is that the law of nations, including that of hospitality, have only, and only could have, a provisional status in Kant's metaphysics.

On the strength of Hunter's account of the thoroughly metaphysical bases of Kant's prioritisation of (necessarily global) communication over property, we gain a much clearer understanding of the instrumental quality of Kant's right of hospitality. For Kant the telos of hospitality is clearly in sight:

In this way, continents distant from each other can enter into peaceful mutual relations which may eventually be regulated by public laws, thus bringing the human race nearer and nearer to a cosmopolitan constitution. ${ }^{124}$

Contra Derridean hospitality, which is the very principle of ethics itself, Kant's universal hospitality is here characterised as no end in itself but as a staging post to cosmopolitan right. ${ }^{125}$ Indeed, it is by comparison 'with this ultimate end' that, first, the inhospitality of European guests in conquering rather than visiting foreign countries is exposed and, second, by which Chinese and Japanese isolationism is revealed as both prudent and legitimate. ${ }^{126}$ 'The peoples of the earth have thus entered in varying degrees into a universal community', and both European inhospitality and East Asian openness to such inhospitable guests would threaten

\footnotetext{
${ }^{121}$ Hunter, 'Kant's Cosmopolitanism from a Historical Viewpoint', p. 23.

122 Ibid., pp. 27-8.

${ }^{123}$ Kant, 'The Metaphysics of Morals', p. 418.

${ }^{124}$ Kant, 'Perpetual Peace', p. 106.

${ }^{125}$ Derrida, Adieu, p. 50; Derrida, On Cosmopolitanism, p. 16. For exemplary recent statements of hospitality as instrumental to cosmopolitan right from a Kantian perspective, see Brown, 'Kantian Cosmopolitan Law' and Garrett W. Brown, 'Moving from Cosmopolitan Legal Theory to Legal Practice: Models of Cosmopolitan Law', Legal Studies, 28:3 (2008), pp. 430-51.

${ }^{126}$ Kant, 'Perpetual Peace', pp. 106 (emphasis added) and p. 107.
} 
this nascent cosmopolitan bond. ${ }^{127}$ After all, states Kant in what has become the most famous phrase of Perpetual Peace, on the basis of the hospitality that enables the communication necessary for embryonic universal community, things have already 'developed to the point where a violation of rights in one part of the world is felt everywhere. ${ }^{128}$

In sum, if this ordering of Kantian hospitality in terms of communication over property is correct then Kant is the mirror of Pufendorf in achieving a greater degree of stabilisation of the two poles of communication-property in hospitality in the name of a right of communication. Yet making international hospitality instrumental to the achievement of a cosmopolitan civil condition under which it would be redundant is also effectively to deny that it is a law of nature. Kant only succeeds in stabilising right of communication-right of property in hospitality by sacrificing hospitality itself. And this in two senses. First, if the right of hospitality derives from the lack of legitimacy of exiting territorial holdings, then once ownership of the earth's surface is legitimated in a cosmopolitan civil order (this argument applies if Kant had a worldwide federation of republics in mind as the instantiation of this order), the normative basis of a right of hospitality is removed - everyone is now rightly entitled to be where they are, but, by extension, have no right to be elsewhere. Second, in a cosmopolitan political community (this version of the argument applies if Kant had a world republic in mind) there are no longer national thresholds to cross, and thereby no requirement for a right of universal hospitality held by individuals in their relations with foreign states. International hospitality is clearly anachronistic in a world in which foreigners have been replaced with co-legislators.

\section{Conclusion}

Derrida has drawn our attention to the 'double bind' of hospitality, expressed here as the paradox that hospitality is constituted both by property and by the openness or communication (the welcome of the stranger) that threatens or may even destroy it. Evidence of this aporia of hospitality is found in abundance in the natural law tradition from Vitoria to Kant. Though this tradition largely (with the instructive exception of Pufendorf) saw the right of communication as a law of nature arising from innate human sociability, the hospitality that this implied proved destabilising of the property claims by which hosts establish their domain as proper to them. As we have seen, all our theorists struggled with this tension, though this struggle took very different forms, from the concern that the law of hospitality might thereby legitimate colonial appropriation to fears for how it could threaten sovereignty. Rather than looking for evolution in the theory of international hospitality, we might then do better to chart the various ways in which the natural lawyers of early European modernity grappled with the 'double bind' of hospitality. While a genealogy of the 'law of hospitality' in the early modern period undoubtedly uncovers discontinuity rather than the singular curve

${ }^{127}$ Ibid., p. 107.

${ }^{128}$ Ibid., pp. 107-8. 
of evolution, one thing remains the same - no matter whose hands it's in, hospitality keeps on deconstructing. The tension between right of property and right of communication which produces the possibility of hospitality also threatens its very existence.

Moreover, we have seen that attempts to get beyond this binary of communication-property, far from resolving this paradox at the heart of international hospitality, were actually fatal to it. Starting with Pufendorf, the tension in hospitality between the right to property (a sovereign community's right to its territory) and the right of communication is resolved in favour of the former. But the cost of the stabilisation effect achieved by Pufendorf in his prioritisation of property over communication is that Pufendorfian hospitality becomes charity, thereby forming part of the 'sorry comfort' of which Kant would later so famously accuse him (along with Grotius and Vattel) in the context of Kant's critique of notions of right based on, and therefore limited by, territory. For Kant, explicitly, hospitality is not 'concerned with philanthropy, but with right', and a cosmopolitan right at that. ${ }^{129}$ But, as we have also seen, while in Kant Pufendorf's imperfect right of hospitality is rearticulated as cosmopolitan right, yet Kant, too, does not escape the double-bind of right of property versus right of communication in hospitality. For Kant's right of hospitality, it turns out, is strictly limited to a right to make contact which may largely be refused. Thus although Kant arguably reverses the Pufendorfian prioritisation of property over communication, the communication he has in mind has been accused of being paltry stuff and doing little, if anything, to challenge right defined territorially. To the extent that this is true, it is perhaps because Kant saw the fearful consequences of a right of hospitality put at the hands of European 'guests'. On this reading, Kant, like Diderot, is aware of the paradox that hospitality is always liable to destroy itself - as when the French explorer Bougainville's generous reception by the Tahitians becomes the opportunity for French colonial appropriation of their island, an inhospitality which Diderot laments in The Supplement to the Voyage of Bougainville (1772). ${ }^{130}$

However, the persuasive argument for Kant's prioritisation of communication over property with which our discussion finished, implies that hospitality is the driver, in Kant, of nothing less than a future global civil condition under which humanity's ownership of the earth's surface might be finally legitimate. But on this reading of his politics, Kant only gets 'beyond' the binary of propertycommunication by overcoming hospitality itself. The universal right of hospitality is only necessary because existing possession of territory remains to be fully legitimated. Once a cosmopolitan civil condition (here: world federation of republics) is achieved, and holdings become truly rightful, the normative foundation of Kant's right of strangers is thereby removed. Alternatively, if the telos of hospitality is nothing less than a world republic, then the right of hospitality is purely provisional - it is only necessary because of the lack of global citizenship; because the international has not yet been domesticated and brought fully under

\footnotetext{
${ }^{129}$ Ibid., p. 105.

${ }^{130}$ Denis Diderot, Supplement to the Voyage of Bougainville, in Denis Diderot: Political Writings, trans. and ed. J. H. Mason and R. Wokler (Cambridge: Cambridge University Press, 1992). For an extended discussion of hospitality in Diderot's Supplement, see Jimmy Klausen, 'Of Hobbes and Hospitality in Diderot's Supplement to the Voyage of Bougainville', Polity, 37:2 (2005), pp. 167-92.
} 
the rule of right; because territorial definitions of rights have still to give way to cosmopolitan right. Yet a transitional right of hospitality is no longer a natural law of hospitality.

As much when the constitutive opposition of communication-property is transcended in the name of the former as the latter, it destroys that which it makes possible. Hospitality cannot live without the destabilising but productive tension between communication and property that is not so much a problem for as the very stuff of it. Focused only on one or the other of the poles of communicationproperty, mainstream International Relations theory can't 'see' hospitality neither its effects (realists) nor its conditions of possibility (idealists). Realist discourse, which finds an antecedent in Pufendorf's prioritisation of domain but which departs from him in forgetting the duties of hospitality by divorcing sovereignty from any conception of wider law, simply overlooks that the sociable welcome of the foreigner in hospitality is an enduring feature of a supposedly anarchic international realm. ${ }^{131}$ Idealist (neo-Kantian) discourse, meanwhile, in seeking a 'beyond' to the distribution of property characteristic of the international in the name of global communication, echoes Kant in consigning hospitality in world politics to an uncertain future. ${ }^{132}$ For hospitality is just as irreducible to communication as it is to property - requiring hosts and foreigners, neither of whom come into being without the property that is the home. The question - right of entry or right of refusal? - which heads this discussion has a definite, if indeterminate, answer: in hospitality, there must be both.

${ }^{131}$ Onuf, 'Friendship and Hospitality'.

${ }^{132}$ Not that hospitality in world politics needs other than the inter- of the inter-national (a world of city-states, for example, would serve just as well as - better than, implies Derrida in On Cosmopolitanism - nation-states). Indeed, whether the figure of the foreigner, a figure which is necessary to the ethics of hospitality, requires territorialisation at all (that is, would hospitality indeed be redundant under conditions of cosmopolitan political community?) is a question for another occasion, one I consider in my book on hospitality in International Relations forthcoming with Routledge. My point here is simply to note the absence of hospitality from contemporary global imaginaries, including visions of cosmopolitan futures. 